\title{
Rate of endogenous methionine oxidation in rats at different levels of methionine intake
}

\author{
By R. J. NEALE \\ Department of Applied Biochemistry and Food Science, University of Nottingham School \\ of Agriculture, Sutton Bonington, Loughborough, Leics. LE12 5RD \\ AND J. C. WATERLOW \\ Department of Human Nutrition, London School of Hygiene and Tropical Medicine, \\ Keppel Street, London WC1E $7 H T$
}

(Received 4 February 1983-Accepted 1 March 1983)

\begin{abstract}
1. The fractional rates of loss of ${ }^{14} \mathrm{C}$ and body-weight were measured in growing female rats after a single dose of $\left[1{ }^{14} \mathrm{C}\right]$ methionine. After the dose, the rats were maintained for $30 \mathrm{~d}$ on diets containing graded amounts of methionine and killed at $30 \mathrm{~d}$.

2. By $20 \mathrm{~d}$ after the dose the level of labelling of body proteins was fairly uniform. From 20 to $30 \mathrm{~d},{ }^{14} \mathrm{CO}_{2}$ was collected at intervals. The rats were killed at $30 \mathrm{~d}$ and the total radioactivity remaining in the body was measured.

3. The fractional loss of ${ }^{14} \mathrm{CO}_{2}$ between days 20 and 30 was constant regardless of methionine intake except at the highest intake level.

4. After correcting the fractional loss of ${ }^{14} \mathrm{CO}_{2}$ for urinary ${ }^{14} \mathrm{C}$ loss, a value of $35 \mathrm{mg} / \mathrm{kg}$ body-weight $(20 \mathrm{mg} / \mathrm{kg}$ body-weight ${ }^{0.75}$ ) was obtained for the rate of endogenous methionine oxidation.
\end{abstract}

In earlier experiments, Neale \& Waterlow $(1974 b, 1977)$ attempted to measure the endogenous oxidation of ${ }^{14} \mathrm{C}$-labelled leucine, lysine and methionine in young and old rats given diets in which these amino acids were absent. This, however, is an artificial condition because it might produce some adaptation (recycling) which does not occur at the maintenance level. In an attempt to attack this problem further, the experiments reported here have measured the rate of oxidation of methionine in growing rats at different levels of methionine intake.

\section{METHODS \\ Animals and diets}

Female Wistar rats weighing approximately $100 \mathrm{~g}$ were used, four to each treatment. They were housed in cages with raised wire-mesh bottoms, four animals per cage. All rats were initially given a low-protein $(39 \mathrm{~g}$ protein $/ \mathrm{kg}$ ) basal diet (Table 1) for a period of $5 \mathrm{~d}$. At 10.00 hours, without a previous fast, the rats were weighed and given $\left[1{ }^{14} \mathrm{C}\right]$ methionine by stomach tube. The rats were then maintained on the basal diet ad lib. for the next $17 \mathrm{~d}$, during which time they were weighed, their food intake recorded and $\mathrm{CO}_{2}$ collected for a single $2 \mathrm{~h}$ period between 10.00 and 16.00 hours every 3-4 d. At $17 \mathrm{~d}$, four groups of rats (groups B-E) were changed to diets of different methionine levels (diets 2-5, Table 1) while group A was maintained on the low-protein basal diet (diet 1). All groups were fed ad lib. Weight was recorded and $\mathrm{CO}_{2}$ was again collected for $2 \mathrm{~h}$ daily between 10.00 and 16.00 hours. Total daily ${ }^{14} \mathrm{CO}_{2}$ output was then estimated by multiplying the $2 \mathrm{~h}$ value by 12 . At day 30, animals were killed and carcasses analysed for ${ }^{14} \mathrm{C}$ radioactivity. $\left[1-{ }^{14} \mathrm{C}\right]$ methionine of specific activity $56.4 \mathrm{mCi} / \mathrm{mmol}$ was obtained from Amersham International, Amersham, Bucks, and diluted with water to give a solution containing $7 \cdot 5 \mu \mathrm{Ci} / \mathrm{ml}$. No carrier amino acid was added. The volume of solution given was $1 \mathrm{ml}$. 
Table 1. Composition $(\mathrm{g} / \mathrm{kg})$ of basal diet (diet 1$)$ and diets with graded levels of methionine (diets 2-5)

\begin{tabular}{lrrrrr}
\hline \hline Diet... & 1 & 2 & 3 & 4 & 5 \\
\hline Casein* & 50 & - & - & - & - \\
Arachis oil & 50 & 50 & 50 & 50 & 50 \\
Dextrinized starch & 300 & 300 & 300 & 300 & 300 \\
Maize starch & 538 & 538 & 538 & 538 & 538 \\
Salt mixture $\dagger$ & 50 & 50 & 50 & 50 & 50 \\
Vitamin mixture $\dagger$ & 11 & 11 & 11 & 11 & 11 \\
L-Methionine & $1 \cdot 0$ & $1 \cdot 09$ & $0 \cdot 73$ & $0 \cdot 36$ & 0 \\
Amino acid mixture & - & 51 & 51 & 51 & 51 \\
\hline
\end{tabular}

* Contains $17.8 \mathrm{~g}$ methionine $/ \mathrm{kg}$ protein (nitrogen $\times 6 \cdot 25$ ).

$\uparrow$ Composition as described by Payne \& Stewart (1972).

¥ Contained L-amino acids in the following amounts $(\mathrm{g} / \mathrm{kg}$ diet): valine 3.48 , arginine hydrochloride 1.91 , histidine hydrochloride monohydrate $2 \cdot 13$, isoleucine $2 \cdot 75$, threonine $2 \cdot 64$, serine $2 \cdot 18$, proline $2 \cdot 18$, leucine $4 \cdot 00$, phenylalanine $3 \cdot 48$, tyrosine $1 \cdot 15$, tryptophan $0 \cdot 94$, lysine hydrochloride $5 \cdot 19$, glycine 4.77 , glutamic acid $14 \cdot 3$,

\section{Analyses}

The rats were killed by chloroform inhalation and whole carcasses including hair, skin and viscera dried to constant weight in a hot-air oven at $105^{\circ}$ for $24-48 \mathrm{~h}$. Carcasses were then broken into small pieces and dissolved overnight in $400 \mathrm{ml} 2 \mathrm{M}$-potassium hydroxide (Neale \& Waterlow $1974 b, 1977)$, boiled to dissolve all resistant tissues and diluted to $1 \mathrm{~kg}$ total slurry weight with distilled water. Bones were discarded. Respiratory $\mathrm{CO}_{2}$ was collected, as previously described, in $50 \mathrm{ml} 2 \mathrm{M}-\mathrm{KOH}$ (Neale \& Waterlow, 1974b). Daily urine was collected on large sheets of filter paper under the cage and extracted with $\mathrm{KOH}$ and water. Fat was not extracted from carcasses in these studies since previous work had shown negligible ${ }^{14} \mathrm{C}$ radioactivity in fat after $\left[1{ }^{14} \mathrm{C}\right]$ methionine injection (Neale \& Waterlow, 1977). Carcass-nitrogen analysis was performed on duplicate, weighed samples from carcass slurry using the macro-Kjeldahl method. Carcass samples were prepared for counting by combustion of known amounts in a Packard Tri-Carb Sample Oxidiser (model 306; Packard Instrument Company, Downers Grove, Illinois, USA). The resulting samples were counted in a Tracerlab liquid scintillation counter (ICN Pharmaceuticals (UK) Ltd, Surrey). All other chemical and radioactive estimations were those previously described (Neale \& Waterlow, 1974a).

\section{CALCULATIONS}

The fractional rate of loss of ${ }^{14} \mathrm{C}$ radioactivity was calculated as described previously (Neale $\&$ Waterlow, $1974 b$ ), i.e. from the mean daily output of ${ }^{14} \mathrm{CO}_{2}$ collected over several days between day 20 and day 30 , divided by the mean amount of radioactivity remaining in the body at the end of $30 \mathrm{~d}$.

The absolute rate of methionine loss was calculated as the fractional rate of loss $\times$ the total methionine content of the non-collagen, non-hair protein in the body. A value of $1.75 \mathrm{~g}$ methionine $/ 100 \mathrm{~g}$ protein (P. J. Reeds, personal communication) was used for this calculation.

\section{RESULTS}

The basal diet (diet 1) containing $50 \mathrm{~g}$ casein $/ \mathrm{kg}$ (39 g protein $/ \mathrm{kg}$ ) (Table 1) was able to support a slow rate of growth in all rats from day 0 to day 17 as shown in Table 2 . Graded levels of methionine given to groups B-E between days 17 and 30 produced variable rates 
Table 2. Body-weights at days 0,17 and 30, rates of change of body-weight between days 17 and 30 and carcass nitrogen at day 30 after giving $\left[1{ }^{14} \mathrm{C}\right]$ methionine to growing, female rats

(Mean values with their standard errors for four rats per group)

\begin{tabular}{|c|c|c|c|c|c|c|c|c|c|c|}
\hline \multirow[b]{2}{*}{ Diet* } & \multirow[b]{2}{*}{ Group } & \multicolumn{2}{|c|}{$\begin{array}{l}\text { Initial body-wt } \\
\text { (g) }\end{array}$} & \multicolumn{2}{|c|}{$\begin{array}{l}\text { Body-wt at } \\
\text { day } 17(\mathrm{~g})\end{array}$} & \multicolumn{2}{|c|}{$\begin{array}{l}\text { Body-wt at } \\
\text { day } 30(\mathrm{~g})\end{array}$} & \multirow{2}{*}{$\begin{array}{l}\text { Rate of body-wt } \\
\text { change between } \\
\text { days } 17 \text { and } 30 \\
\text { (g/kg body-wt per } \mathrm{d} \text { ) }\end{array}$} & \multicolumn{2}{|c|}{$\begin{array}{c}\text { Carcass } N \text { at } \\
\text { day } 30(\mathrm{~g} / \mathrm{kg} \\
\text { body-wt) }\end{array}$} \\
\hline & & Mean & SE & Mean & SE & Mean & SE & & Mean & SE \\
\hline 1 & A & $105 \cdot 9$ & 3.0 & $120 \cdot 9$ & $7 \cdot 5$ & $124 \cdot 8$ & $7 \cdot 3$ & +3.90 & $2 \cdot 67$ & $0 \cdot 21$ \\
\hline 2 & B & $110 \cdot 7$ & 0.9 & $111 \cdot 0$ & $3 \cdot 1$ & $108 \cdot 5$ & $2 \cdot 5$ & $-2 \cdot 50$ & $2 \cdot 45$ & 0.18 \\
\hline 3 & $\mathrm{C}$ & $112 \cdot 1$ & 3.4 & $121 \cdot 4$ & $2 \cdot 9$ & $114 \cdot 2$ & $2 \cdot 3$ & $-7 \cdot 20$ & $2 \cdot 06$ & $0 \cdot 12$ \\
\hline 4 & D & $104 \cdot 3$ & $3 \cdot 5$ & 124.4 & $2 \cdot 7$ & $113 \cdot 3$ & $2 \cdot 7$ & $-11 \cdot 1$ & $2 \cdot 38$ & $0 \cdot 13$ \\
\hline 5 & $\mathrm{E}$ & $110 \cdot 4$ & $3 \cdot 7$ & $118 \cdot 8$ & $7 \cdot 0$ & 104.9 & 6.8 & $-13 \cdot 9$ & $2 \cdot 62$ & 0.22 \\
\hline
\end{tabular}

* For details, see Table 1.

of body-weight loss, group E, on the methionine + cystine-free diet (diet 5), showing the greatest weight loss and being similar to that shown in adult male rats previously (Neale \& Waterlow, 1977). Group A on diet 1 continued to gain weight slowly between days 17 and 30. Food intake on diets 1-5 became stable on day 19 and 20 after adjustment to the change in diet and was $130,111,119,121$ and $87 \cdot 4 \mathrm{~g} / \mathrm{kg}$ rat per d on diets $1-5$ respectively. Carcass $\mathrm{N}$ expressed in $\mathrm{g} \mathrm{N} / 100 \mathrm{~g}$ body-weight showed no significant differences between groups, except for group $\mathrm{C}$ in which it was somewhat lower. No explanation can be given for this result.

$$
\text { Loss of }{ }^{14} \mathrm{CO}_{2}
$$

No measurements of ${ }^{14} \mathrm{CO}_{2}$ loss immediately after injection of the $\left[1-{ }^{14} \mathrm{C}\right]$ methionine were made in these studies but previous observations showed this to be very high $(9 \%$ original ${ }^{14} \mathrm{C}$ dose) after only $2 \mathrm{~h}$ (Neale \& Waterlow, 1977).

Measurements made subsequently, however, showed average daily losses (\% dose) of $2 \cdot 14$ on day $3,0.89$ on day $7,0.53$ on day 10 and 0.43 on day 15 . After the change of diet at day 17 , subsequent losses for all groups between days 20 and 30 were fairly constant; average values for all groups are shown in Table 3. It must be emphasized that the ${ }^{14} \mathrm{CO}_{2}$ values were obtained when rats were in the post-absorptive state and would have been at the nadir of the diurnal ${ }^{14} \mathrm{CO}_{2}$ excretion (Wannemacher \& Dinterman, 1980).

\section{Retention of ${ }^{14} \mathrm{C}$ in the body and urinary $-{ }^{14} \mathrm{C}$ loss}

The ${ }^{14} \mathrm{C}$ retained in the body $30 \mathrm{~d}$ after injection of $\left[1-{ }^{14} \mathrm{C}\right]$ methionine, as a percentage of the original ${ }^{14} \mathrm{C}$ dose given, was as follows: group A $22 \cdot 8$, group B $24 \cdot 7$, group C $26 \cdot 4$, group D $24 \cdot 2$, group E $24 \cdot 3$. It was clear that there was little difference in final total body ${ }^{14} \mathrm{C}$ radioactivity whatever diet was fed.

Urinary ${ }^{14} \mathrm{C}$ loss was estimated by daily collection of urine from all five groups. An average value of $5 \%$ total daily loss was measured. No measurements were made of faecal losses but these were assumed to be negligible.

\section{Fractional and absolute rates of methionine loss}

The fractional rates of ${ }^{14} \mathrm{C}$ loss from groups $\mathrm{B}-\mathrm{E}$ were nearly equal, and lower than that of group A (Table 3). The endogenous rates of loss of methionine have been calculated as the product of the fractional rate and the total methionine content of the rat (Table 3 ). The 
Table 3. Mean loss of radioactivity as ${ }^{14} \mathrm{C}$-labelled carbon dioxide, fractional rate of loss of ${ }^{14} \mathrm{C}$ radioactivity and absolute loss of methionine between 20 and $30 \mathrm{~d}$ after giving (1-14 C]methionine to growing, female rats

(Mean values with their standard errors, where given, for four rats per group)

\begin{tabular}{|c|c|c|c|c|c|c|c|}
\hline \multirow[b]{2}{*}{ Group } & \multirow[b]{2}{*}{ Diet* } & \multicolumn{2}{|c|}{$\begin{array}{c}{ }^{14} \mathrm{CO}_{2} \text { loss }(\% \\
\text { original dose } / \mathrm{d})\end{array}$} & \multicolumn{2}{|c|}{$\begin{array}{l}\text { Fractional rate of } \\
{ }^{14} \mathrm{CO}_{2} \text { loss }(\% \\
\text { remaining/d) }\end{array}$} & \multicolumn{2}{|c|}{ Absolute loss } \\
\hline & & Mean & $\mathrm{SE}$ & Mean & $\mathrm{SE}$ & $\begin{array}{c}\mathrm{mg} / \mathrm{kg} \\
\text { body-wt }\end{array}$ & $\begin{array}{c}\mathrm{mg} / \mathrm{kg} \\
\text { body-wt }\end{array}$ \\
\hline A & 1 & 0.346 & 0.02 & $1 \cdot 52$ & 0.09 & $41 \cdot 4$ & $23 \cdot 2$ \\
\hline B & 2 & 0.319 & 0.01 & $1 \cdot 29$ & 0.05 & $35 \cdot 2$ & $19 \cdot 7$ \\
\hline $\mathrm{C}$ & 3 & 0.334 & 0.02 & $1 \cdot 26$ & 0.09 & $34 \cdot 3$ & $19 \cdot 2$ \\
\hline D & 4 & 0.306 & 0.02 & $1 \cdot 26$ & 0.09 & $34 \cdot 3$ & $19 \cdot 2$ \\
\hline $\mathrm{E}$ & 5 & 0.309 & 0.01 & $1 \cdot 27$ & 0.05 & $34 \cdot 6$ & $19 \cdot 4$ \\
\hline
\end{tabular}

* For details, see Table 1 .

Table 4. Methionine intake, methionine content of weight lost or gained, methionine oxidized and methionine unaccounted for in growing, female rats $30 \mathrm{~d}$ after giving $\left[1-{ }^{14} \mathrm{C}\right]$ methionine

(All values calculated per $\mathrm{kg}$ rat)

\begin{tabular}{ccccc}
\hline \hline Group & $\begin{array}{c}\text { Methionine } \\
\text { intake } \\
(\mathrm{mg} / \mathrm{d})\end{array}$ & $\begin{array}{c}\text { Methionine content of } \\
\text { weight lost or gained } \\
(\mathrm{mg} / \mathrm{d}) \\
(\mathrm{G})\end{array}$ & $\begin{array}{c}\text { Methionine } \\
\text { oxidized } \\
(\mathrm{mg} / \mathrm{d}) \\
(\mathrm{O})\end{array}$ & $\begin{array}{c}\text { Methionine } \\
\text { unaccounted for } \\
(\mathrm{mg} / \mathrm{d}) \\
(\mathrm{I}-\mathrm{G}-\mathrm{O})\end{array}$ \\
\hline A & 255 & $+10 \cdot 6$ & $41 \cdot 4$ & 203 \\
B & 121 & $-6 \cdot 8$ & $35 \cdot 2$ & 94 \\
C & $86 \cdot 8$ & $-19 \cdot 7$ & $34 \cdot 3$ & 72 \\
D & 42.6 & -30.3 & $34 \cdot 3$ & 39 \\
E & 0 & -37.9 & 34.6 & 3.3 \\
\hline \hline
\end{tabular}

$\mathrm{G}$, calculated from weight change $(\mathrm{g} / 100 \mathrm{~g}$ body-weight (Table 2$)) \times$ total body methionine $(273 \mathrm{mg} / 100 \mathrm{~g})$; negative if weight lost; $O$, from Table 3 .

calculation is based on a value of $1.75 \mathrm{~g}$ methionine $/ 100 \mathrm{~g}$ protein $(109 \mathrm{mg}$ methionine $/ \mathrm{g} \mathrm{N}$ ) (P. J. Reeds, personal communication). Total body-N is taken as $25 \mathrm{~g} / \mathrm{kg}$ body-weight (Waterlow \& Stephen, 1966). These values give total body methionine $=2725 \mathrm{mg} / \mathrm{kg}$ body-weight.

The relationship between methionine intake, methionine oxidized and change in body methionine content

Table 4 shows a calculation of apparent methionine balance. The apparent balance $=$ (methionine intake) $+/$ - (methionine content of tissue lost/gained) - (protein-bound methionine oxidized). The table shows that apparent balance is achieved only at zero methionine intake. The greater the intake, the larger the amount of methionine unaccounted for. The possible reasons for this will be considered in the discussion. 


\section{DISCUSSION}

The primary objective of this work was to measure the rate of irreversible endogenous oxidation of methionine in the rat, as a basis for determining the methionine requirement. We have reported previous studies with leucine and lysine with the same experimental design (Neale \& Waterlow, 1974b, 1977). The endogenous amino acid oxidation is conceptually equivalent to the obligatory loss of total $\mathbf{N}$ (Food and Agriculture Organization/World Health Organization, 1973). In both cases the minimum dietary intake needed to replace the losses, i.e. the requirement, will be greater than the loss because utilization is unlikely to be $100 \%$ efficient. In these experiments we have not been able to determine the efficiency of utilization. The figure we have obtained represents the theoretical minimum requirement, if utilization of dietary methionine were $100 \%$ efficient.

The validity of the results depends upon assumptions discussed in previous papers (Neale $\&$ Waterlow, 1974b, 1977) that under the experimental conditions chosen there is reasonably uniform labelling of body proteins and that re-utilization of the ${ }^{14} \mathrm{C}$ atom by uptake into other amino acids is negligible once it has been detached from methionine. The latter assumption seems justified by the very large dilution which occurs in the bicarbonate pool. If these two assumptions are accepted, it can be concluded that the fractional rate of loss of ${ }^{14} \mathrm{CO}_{2}$ is equal to the fractional rate of oxidation of protein-bound methionine.

The next step is to convert the fractional into an absolute rate of loss. For this we need to know the size of the protein-bound methionine pool from which the ${ }^{14} \mathrm{CO}_{2}$ is derived. The value used in Table 3 was based on measurements made on the whole rat. It may be contended that this over-estimates the size of the methionine pool which is turning over, because the whole rat contains some protein-bound methionine which is virtually not turning over, for example, in connetive tissue and in hair. To check this point we have made an independent calculation of the methionine pool size. From the results of Waterlow \& Stephen (1966) it may be assumed that $70 \%$ of whole-body protein in the rat is non-collagen, non-hair protein. We further assume that the methionine content of muscle is representative of that of all non-collagen, non-hair protein. The methionine content of rat muscle was found by E. B. Fern (personal communication) to be $150 \mathrm{mg} / \mathrm{g} \mathrm{N}$. From these values the size of turning-over methionine pool may be calculated as $(150 \times 0.7 \times 25)=2625 \mathrm{mg} / \mathrm{kg}$ body-weight. This is only $4 \%$ less than the figure based on whole-body analysis, so that the values in Table 3 for the absolute rate of methionine oxidation are not likely to be in serious error. As shown in the results section, the outcome of these calculations is a value of $35 \mathrm{mg} / \mathrm{kg}$ rat per $\mathrm{d}$ for the endogenous methionine loss. This is lower than Said \& Hegsted's (1970) estimate of $77 \mathrm{mg} / \mathrm{kg}$ per d $\left(43 \mathrm{mg} / \mathrm{kg}\right.$ body-weight $\left.t^{0.75}\right)$ as the requirement of methionine without cystine.

A second objective of this experiment was to find out whether there is any evidence of adaptation in the rate of endogenous methionine oxidation at different levels of methionine intake. The results in Table 3 show that in all the groups of rats who were losing weight, the rate of endogenous oxidation was the same. However, in the rats of group A, which were gaining weight, the rate of oxidation was slightly higher. The conclusion seems to be that below the level of maintenance (zero weight change) there is no further adaptation.

Although it was not part of the objective of this study, it seemed of interest to examine the methionine balance in these rats (Table 4). In all rats, except those on zero methionine intake, there was a substantial amount of methionine unaccounted for, an amount which increases with increasing intake. Theoretically, the net balance $=$ intake-loss. In group C, for example, with intake $87 \mathrm{mg}$ and endogenous loss $35 \mathrm{mg}$ methionine $/ \mathrm{kg}$ rat per d, after allowing for theoretical methionine content lost in body-weight, there should be a positive balance of $72 \mathrm{mg} / \mathrm{kg}$ rat per $\mathrm{d}$. This discrepancy becomes even greater if one assumes that 
the small amounts of weight lost include a loss of protein and therefore of methionine (see Table 4). In the five groups of rats the methionine unaccounted for amounted to $\mathrm{A}+203$, $\mathrm{B}+94, \mathrm{C}+72, \mathrm{D}+39, \mathrm{E}+3 \cdot 3 \mathrm{mg}$ methionine $/ \mathrm{kg}$ rat per $\mathrm{d}$. What has happened to this methionine?

(1) Storage in the free form seems unlikely on general grounds.

(2) Retention as newly deposited protein seems unlikely because all the rats except those of group A lost weight. Theoretically, the rats could be in positive nitrogen balance and negative energy balance, but then the $\mathrm{N}$ concentration in the body should be higher in the groups supposedly 'storing' more methionine. The values in Table 2 (last column) show that this was not so.

(3) Some loss will be occurring from the desquamation of hair. We have no measure of its magnitude, but it seems highly unlikely that it will vary in this way with the dietary intake.

(4) The most reasonable explanation seems to be that the unmeasured losses represent oxidation of unlabelled methionine from the food.

If point 4 is the explanation, two conclusions follow. First, the losses are surprisingly high. For example, in group $\mathrm{C}$, even if the efficiency of utilization of dietary methionine was only $50 \%$, the intake should have been enough to balance the endogenous loss and preserve a steady-state without weight loss. These results, therefore, suggest that methionine was not the limiting factor in the diet of these rats, and that they were getting surplus methionine which they could not utilize for growth. Even if that is so, it in no way invalidates the conclusions drawn about the rate of endogenous oxidation.

The second point is that if the methionine unaccounted for in the balance equation represents dietary methionine with is oxidated, then it implies that there is incomplete mixing in the free amino acid pool between dietary methionine and methionine derived from the oxidation of protein. If mixing were complete, on the higher methionine intakes there should be a larger excretion of ${ }^{14} \mathrm{CO}_{2}$, because a smaller proportion of the labelled methionine liberated by protein breakdown would be reutilized for protein synthesis. It must, of course, be borne in mind that the measurements ${ }^{14}{ }^{14} \mathrm{CO}_{2}$ output were made with the rats in the post-absorptive state, when they were not receiving food and thus at the nadir of ${ }^{14} \mathrm{CO}_{2}$ output (Wannemacher \& Dinterman, 1980).

This question of the completeness of mixing is clearly one which needs further investigation.

\section{REFERENCES}

Food and Agriculture Organization/World Health Organization (1973). Technical Report Series of the World Health Organization No. 522.

Neale, R. J. \& Waterlow, J. C. (1974a). British Journal of Nutrition 32, 11-25.

Neale, R. J. \& Waterlow, J. C. (1974b). British Journal of Nutrition 32, 257-272.

Neale, R. J. \& Waterlow, J. C. (1977). British Journal of Nutrition 37, 259-268.

Payne, P. R. \& Stewart, R. J. C. (1972). Laboratory Animals 6, 135-140.

Said, A. K. \& Hegsted, D. M. (1970). Journal of Nutrition 100, 1363-1376.

Wannemacher, R. W. \& Dinterman, R. E. (1980). Biochemical Journal 190, 663-671.

Waterlow, J. C. \& Stephen, J. M. L. (1966). British Journal of Nutrition 20, 461-484. 